\title{
Elena Wynalek
}

Baszkirski Państwowy Uniwersytet Pedagogiczny im. M. Akmułly w Ufie

\section{NAUCZANIE JĘZYKA POLSKIEGO I ROSYJSKIEGO JAKO OBCEGO W OPARCIU O WYBRANE ZNACZĄCE DZIELA KULTURY OBU NARODÓW NA PRZYKLADZIE POEMATÓW ADAMA MICKIEWICZA PAN TADEUSZ I ALEKSANDRA PUSZKINA EUGENIUSZ ONIEGIN}

SŁOWA KLUCZOWE: tekst kultury, dydaktyka języków obcych, stopień znajomości języka, ćwiczenie językowe, analiza tekstu

W nauczaniu języka często stosujemy jako materiał do ćwiczeń ważne dla kultury danego kraju teksty. Jest to szczególnie istotne także w nauczaniu języka jako obcego. Za pomocą takich tekstów pomagamy uczniom poznawać kulturę kraju, w którym tym językiem bedą się posługiwać.

W nauczaniu języka polskiego jako obcego takim tekstem może zostać Pan Tadeusz Adama Mickiewicza. Powszechnie wiadomo, że poemat ten jest epopeją narodową, biblią polskości, jednym z najważniejszych dzieł literatury polskiej, chociaż trzeba zdać sobie sprawę, że język Pana Tadeusza nie jest polszczyzną współczesną. Dlatego niezbędnym jest udzielanie, poznającemu język i kulturę polską ucznia, komentarzy kulturologicznych, m.in. na przykładzie fragmentu o bigosie (jedno z reprezentacyjnych dań kuchni polskiej), opisu ubrania Zosi w Księdze Jedenastej („,narodowa szata”) itp.

W przypadku nauczania języka polskiego jako obcego uczniów rosyjskojęzycznych ciekawym wydaje się porównanie znaczących tekstów kultury. W rosyjskiej literaturze takim tekstem może być poemat Aleksandra Puszkina Eugeniusz Oniegin.

Oba dzieła, które na pierwszy rzut oka bardzo się różnią, mają jednak ze sobą wiele wspólnego. Są w nich opisane jednakowe realia (odzież, jedzenie, gospodarstwo, wystrój pokoi), jednakowe sytuacje (uczta i święto w domu Larynych i u Sędziego, ,jarmark panien" w Moskwie i towarzystwo w domu Sędziego w pierwszych księgach, wychowanie młodego człowieka, pojedynkowanie się).

W chwili obecnej wykonuję projekt ,Zabawy, spory w one lata... " (Kultura życia codziennego arystokracji rosyjskiej $i$ polskiej szlachty $w$ XIX w. na podstawie poematów Adama Mickiewicza „Pan Tadeusz” i Aleksandra Puszkina „Eugeniusz 
Oniegin") finansowany przez Centrum Polsko-Rosyjskiego Dialogu i Porozumienia. Wynikiem projektu będzie monografia zawierająca badanie kulturologiczne kultury życia codziennego Rosjan i Polaków. Badanie to będzie miało wartość nie tylko naukową, ale również praktyczną. W monografii przewidziany jest rozdział metodyczny, opisujący koncepcję i scenariusze lektur z Pana Tadeusza i Eugeniusza Oniegina w szkole polskiej i rosyjskiej na podstawie przeprowadzonego badania. Scenariusze i koncepcje te będą również realizowane w placówkach dydaktycznych w Rosji i w Polsce. W badaniu wezmą udział: Niedzielna Szkoła Polska w Ufie (lekcje języka polskiego jako obcego, lekcje literatury polskiej), Szkoła Średnia nr 100 w Ufie (lekcje literatury rosyjskiej, kółko języka polskiego) oraz Zespół Szkół Gminy Olecko (lekcje z języka polskiego, z jezyka rosyjskiego jako obcego). W badaniu weźmie także udział Baszkirski Państwowy Uniwersytet Pedagogiczny im. M. Akmułły w Ufie, którego filią jest Szkoła Średnia nr 100 w Ufie. Celem zajęć będzie:

- zapoznanie uczniów z największymi dziełami literatury polskiej i rosyjskiej (chociaż wymienione dzieła literackie zajmują swoje miejsce w literaturze nie tylko narodowej, ale również światowej, uczniowie szkół rosyjskich, a nawet dorośli miłośnicy literatury mało znają Pana Tadeusza, nie każdy przeciętny Rosjanin przeczytał poemat Mickiewicza; również w Polsce są miłośnicy Puszkina, ale w szkole polskiej nie ma lektur z twórczości tego poety);

- poznawanie na podstawie wymienionych tekstów kultury obu krajów (tzw. lekcja syntetyczna w ujęciu dydaktycznej tradycji rosyjskiej, czyli lekcja zawierająca w sobie informacje $\mathrm{z}$ kilku przedmiotów przy nauczaniu jednego tematu, wątku albo zjawiska. Przy takim podejściu wydzielamy zwykle wiodący przedmiot i dyscypliny wspomagające);

- zainteresowanie uczniów obcą kulturą i literaturą, aby zmobilizować i zachęcić ucznia do dalszego samokształcenia w tym kierunku.

Szkoła rosyjska w odróżnienu od szkoły polskiej dzieli materiał programowy z języka i literatury na 2 przedmioty: Język rosyjski i Literatura rosyjska. Lektura z Eugeniusza Oniegina odbywa się w 9 klasie w ramach przedmiotu Literatura rosyjska, według różnych programów edukacyjnych [Курдюмова и пр., 2006; Киселев и пр., 2010; Программа по литературе..., 2008], zaplanowano na to 7-9 godzin. Uwaga we wszystkich programach przy lekturze skupia się na charakterystyce postaciach Eugeniusza Oniegina, Lenskiego, Olgi i Tatiany oraz na rozpatrzeniu cech całego poematu jako utworu lirycznego i jako „encyklopedii życia rosyjskiego" (przeznacza się na to zwykle 1 godzinę). Analizując scenariusze lekcji poświęconych ostatniemu tematowi można powiedzieć, iż rzadko nauczyciel stara się w pełni przeanalizować z uczniami realia życia codziennego w poemacie, mówiąc o realizmie, epiczności, liryzmie w utworze; czasami zwraca się uwagę na jeden $\mathrm{z}$ aspektów życia codziennego, np. jedzenie (spotkałam w Internecie kilka propozycji scenariuszy lekcji, w których chodzi o jedzenie i dania, chociaż temat lekcji brzmi: Eugeniusz 
Oniegin encyklopedia życia rosyjskiego). W ramach przedmiotu Język rosyjski można spotkać fragmenty z Eugeniusza Oniegina jako materiał dla różnego rodzaju ćwiczeń językowych. W młodszych klasach uczniowie zapoznawają się z fragmentami z Eugeniusza Oniegina, opisującymi przyrodę (najsłynniejsze to: Już dzień się kończyt coraz wcześniej..., Jaśniej niż sal posadzka gładka..., Zima!... Wesoło pohukując...). Przy czym fragmenty te są podane jako wiersze autorstwa A. Puszkina i wcale nie jest zaznaczone $\mathrm{w}$ podręczniku, że to są fragmenty słynnego poematu, chociaż zna je na pamięć prawie każdy Rosjanin.

W szkole polskiej poznawanie przez uczniów Pana Tadeusza rozpoczyna się w gimnazjum. W tym okresie uczniom zaproponowane są do czytania tylko fragmenty poematu. W odróżnianu od szkoły rosyjskiej zawsze jest podkreślane, że to są fragmenty słynnego dzieła A. Mickiewicza. Zawierają one również najczęściej opisy przyrody (np. opis ogródka Zosi z Księgi Pierwszej, opis dwóch stawów i młynu z Księgi Ósmej, walkę z niedźwiedziem z Księgi czwartej) i są podawane po to, żeby nauczyć uczniów analizować tekst poetycki. Natomiast w szkole ponadgimnazjalnej według starej i nowej podstawy programowej należy uczniom zalecić Pana Tadeusza do przeczytania w całości. Po przeanalizowaniu 3 podręczników z języka polskiego [Rosiek i in., 2003; Nawarecki i Siwicka, 2009; Miazga i Majerowski, 2011] można stwierdzić, że główne tematy ukazujące się we wszystkich podręcznikach to: gatunki literackie w poemacie; obraz ojczyzny, tradycja i historia; przyroda w Panu Tadeuszu. Mam wrażenie, że w szkole polskiej przy tej lekturze większą uwagę zwracano na rozpatrzenie realiów życia codziennego niż w szkole rosyjskiej przy lekturze Eugeniusz Oniegina.

Analizowane tematy w nauczaniu obu poematów w szkole pozwalają znaleźć wspólne punkty, na podstawie których można byłoby zbudować zajęcia, polegające na porównywaniu poematów z punktu widzenia kulturoznawczego, nie odbiegając za bardzo od programu podstawowego, jedynie pogłębiając go. Mogą to więc być lekcje poświęcone: 1) ogólnej analizie obu poematów jako „encyklopedii życia”, znalezieniu wspólnych tematów (opisanie gospodarstwa, pojedynku, historia kształcenia młodego człowieka, etykieta na spotkaniu towarzyskim, kuchnia i jedzenie), cech różnych gatunków literackich (epopeja, poemat, powieść itd.); 2) rozpatrzeniu realiów historycznych (ubrania, postacie historyczne, miejsca historyczne itp.) i tradycji narodowych w poematach (wróżby w Eugeniuszu Onieginie, odprawianie mszy, zajazdy w Panu Tadeuszu); 3) na podstawie analizy postaci z obu dzieł można zaproponować uczniom rozpoznanie bohaterów-sobowtórów (Eugeniusz i Hrabia, Leński i Hrabia, Zosia i Tatiana, Telimena i księżna Alina, Sędzia i Dymitr Larin, Sędzia i wujek Eugeniusza), przeanalizowanie ich wspólnych i odmiennych cech. Pierwsze dwie propozycje uzupełniłyby brak analizy ogólnej Eugeniusza Oniegina na lekcjach w szkole rosyjskiej, ostatnia propozycja uzupeniłaby braki szczegółowej charakterystyki głównych postaci Pana Tadeusza na lekcjach w szkole polskiej. Wymienione tematy mogą być wybrane (wskazane) zarówno w ramach nauczania literatury w szkole rosyjskiej i w ra- 
mach przedmiotu Język polski w szkole polskiej, jak i w nauczaniu języków polskiego i rosyjskiego jako obcych.

Sprawą oczywistą pozostaje fakt, że takie lekcje muszą być poprzedzone dodatkową pracą, która ma na celu zapoznanie uczniów z dziełem literackim, którego oni nie mają w programie szkolnym (dla polskich uczniów to Eugeniusz Oniegin, dla rosyjskich - Pan Tadeusz). Praca ta może być przeprowadzona w następujący sposób:

1. Nauczyciel zadaje uczniom przeczytanie poematu w domu jako dodatkową lekturę (szkoła średnia w Rosji, szkoła gimnazjalna i ponadgimnazjalna w Polsce).

2. Nauczyciel w ramach zajęć szkolnych, w ciągu kilku lekcji zapoznaje uczniów z dziełem literackim. Możliwość taka istnieje dla nauczycieli i uczniów Niedzielnej Szkoły Polskiej w Ufie, gdzie nauczyciel według swoich własnych intencji może zmieniać treść zajęć w zależności od liczby uczniów i ich wieku (do niedzielnej szkoły uczniowie przychodzą dobrowolnie w różnym wie$\mathrm{ku}$, istnieją klasy ze względu na starszy, średni i młodszy poziom nauczania) oraz programu kulturowego zaplanowanego w bieżącym roku (szkoła ściśle współpracuje z Centrum Kultury i Oświaty Polskiej i aktywnie uczestniczy w jego imprezach kulturalnych, obie placówki mają wspólny plan działań). Przy tym fragmenty poematu mogą by czytane po polsku i po rosyjsku według życzenia nauczyciela i jego celów dydaktycznych.

3. Wśród uczniów klas średnich szkoły rosyjskiej (5-8 klasy) i polskich gimnazjów dobrym tematem dla lekcji będzie: Przyroda $w$ dzietach Puszkina i Mickiewicza. Klimat Rosji i Polski bardzo się różni. Tak się stało, że Puszkin w swoim dziele daje piękne opisy później jesieni i zimy, pejzażów, które rzadko można spotkać w Polsce - całkiem zamrożona rzeka, wielkie zaspy śniegu, ostry mróz, który bardzo szkodliwie może oddziaływać na organizm (wspomnijmy urwisa, [który] odmrozit sobie palec). Natomiast w Panu Tadeuszu spotykamy pejzaże letnie, bo główna akcja poematu obejmuje tylko 5 letnich dni. W tym temacie sensowną wydaje się propozycja nauczyciela, w ramach nauczania języka jako obcego, przeczytać słynne fragmenty z Mickiewicza i Puszkina i porównać opisane pejzaże z tym, co uczniowie widzą za oknem. Uczniowie mogą odpowiedzieć na pytania: czy są w Polsce takie mrozy jak w Rosji; czy podobna jest pogoda w Polsce i w Rosji w pażdzierniku, jak to opisuje Puszkin we fragmencie Już dzień się kończyt coraz wcześniej...; czy spotyka się w Rosji takie jeziora, jak w opisie Mickiewicza; czy widział ktoś z uczniów rosyjskich młyn podobny do mickiewiczowskiego; czy w Rosji i Polsce rosną podobne rośliny itd. Oczywiście taki materiał będzie dobrym dla nauczania się obcych słów z grup tematycznych „Przyroda”, „Pogoda”.

4. W klasach naczelnych w Rosji (w polskiej — szkole podstawowej), na młodszym poziomie nauczania w Niedzielnej Szkole Polskiej w Ufie lektury mogą 
być prowadzone bez specjalnych przygotowań, gdyż uczniowie w tym wieku jeszcze nie mieli lektur ani z Pana Tadeusza w szkole polskiej, ani z Eugeniusza Oniegina w szkole rosyjskiej. Zajęcia takie posłużą zatem jako wprowadzenie do przyszłych lektur. W takiej lekcji głównym materiałem oczywiście musi stać się nie materiał literaturoznawczy tylko językowy, którego nauczanie musi być oparte na jednym albo na obu wymienionych tekstach. Wielkim powodzeniem wśród uczniów 6 klasy Szkoły Średniej nr 15 w Ufie cieszyła się przeprowadzona na tej zasadzie lekcja z języka rosyjskiego pt. Imiesłowy. Za materiał językowy posłużyły fragmenty z utworu Słowo o pułku Igora, eposu starorosyjskiego, lektury, która jest zaplanowana w programie nauczania w 9 klasie [Слободян, 2008].

Poza lekcjami można zaproponować uczniom następujące formy aktywności dla lepszego poznawania świata obu poematów: konkurs rysunków i ilustracji do obu poematów, zadania twórcze polegające na napisaniu stylizacji albo parodii na Eugeniusza Oniegina albo Pana Tadeusza (parodie na Eugeniusza Oniegina w rosyjskiej tradycji folklorystycznej są liczne, mają długą historię i mogłyby stać tematem oddzielnego rozważania naukowego), eksperyment kulturologiczny polegający na przeniesienu bohaterów z Eugeniusza Oniegina do realiów eposu Pan Tadeusz i odwrotnie, możliwe tu są opracowania na przykładowe tematy: Co byłoby gdyby Eugeniusz Oniegin znalazł się w Soplicowie?, Kariera Tadeusza Soplicy w Petersburgu, Czy mogliby się przyjaźnić Eugeniusz Oniegin i Hrabia, Czy mogliby się przyjaźnić Hrabia i Włodzimierz Lenski; konkurs recytacji, szkolny teatrzyk (Imieniny u Larynych, odwiedziny Larynych przez Eugeniusza i Leńskiego, spotkanie z Tatianą w Petersburgu, sen Tatiany; kolacja u Sędziego w Księdze Pierwszej, spór o charty, Tadeusz i Telimena, anegdota petersburska Telimeny, spotkanie Hrabiego i Zosi w sadzie, pożegnania Tadeusza i Hrabiego z Księgi Dziesiątej), szkolne gazetki. Takie formy aktywności można zaproponowa uczniom tak w języku ojczystym, jak i obcym.

Jako materiał faktologiczny radzę korzystać oczywiście z oryginalnych tekstów. W razie potrzeby, np. na zajęciach z języka obcego albo w klasach z niskim poziomem znajomości języka obcego, można korzystac z przekładów. W przypadku wprowadzania Eugeniusza Oniegina w szkole polskiej radziłabym korzystać jedynie z „klasycznego” przekładu Adama Ważyka, chociaż istnieje kilka przekładów poematu na język polski. Przekład Adama Ważyka wykonany w XX wie$\mathrm{ku}$ jest najbardziej dostępnym i rozpowszechnionym, stąd najprawdopodobniej uczniowie w domu poza zajęciami będą czytali właśnie tę pozycję. Inne przekłady pochodzą z XIX-tego i z przełomu XIX i XX-tego wieku, więc polszczyzna, którą posługiwali się tłumacze może dla współczesnych dzieci okazać się archaiczną i niezrozumiałą. Istnieją trzy przekłady Pana Tadeusza wykonane w wieku XX, które mogą być jednakowo dobrze wykorzystane w szkole rosyjskiej w celach zapoznania się uczniów z eposem. Za przekład „klasyczny” uważa się pracę S. Akse- 
nowej-Mar, który najczęściej można spotkać w bibliotekach rosyjskich. Dwa inne przekłady, M. Pawłowej i nowoczesny przekład S. Swiackiego, spotyka się znacznie rzadziej. Przekład Swiackiego jest rozpowszechniany przez polskie placówki dyplomatyczne w Rosji wśród środowisk polonyjnych i będzie wykorzystany na zajęciach w Niedzielnej Szkole Polskiej w Ufie.

Wymienione rodzaje i formy zajęć porównawczych mogłyby stać się nie tylko bodźcem dla ciekawych rozważań kulturoznawczych i ćwiczeń językowych (porównanie przekładu i oryginału, czytanie dzieła literatury ojczystej w jezyku obcym, porównanie opisów jednakowych sytuacji w dwóch dziełach), ale także pomogłoby utrwalać pozytywny obraz Polaka w oczach Rosjan i odwrotnie. Cel taki jest zgodny z wypowiedzią dra Hieronima Grali (na konferencji Polska Polityka Wschodnia w 2011, w panelu Rusofile i rusofobi. Jak racjonalnie rozmawiać z Rosją?) o strategicznych zadaniach polskich placówek dyplomatycznych na Wschodzie.

\section{Bibliografia}

Курдюмова Т. Ф., ДЕмидовА Н. А., КоЛОКольцев Е. Н. и ДР., 2006, Литература: программа по литературе для общеобразовательных учреждений. 5-11 класс, Москва.

Киселев А. К., Кутузов А. Г., РоманичевА Е. С., 2010, Литература. Программа для общеобразовательных учреждений. 5-11 класс, Москва.

Коровин В. Я. (red.), 2008, Программа по литературе. 5-11 классы (базовый уровень), Москва.

Rosiek S. i in., 2003, Między tekstami. Język polski. Podręcznik dla liceum i technikum. Zakres podstawowy i rozszerzony. Część 3: Romantyzm (Echa współczesne), Gdańsk.

Nawarecki A., Siwicka D., 2009, Przeszłość to dziś. Literatura, język, kultura. Klasa 2., Część 1, Warszawa.

Miazga M., Majerowski A., 2011, Zrozumieć tekst — zrozumieć człowieka. Język polski, klasa 2, Warszawa.

Словодян Е., 2008, Использование Параллельного корпуса переводов „Слова о полку Игореве” в преподавании русского языка в школе [w:] Материальы ХІХ Международной конференции „Применение новых технологий в образовании”. 26-27 июня 2008 г., Троицк, s. 214-217. 